As the Nation's principal conservation agency, the Department of the Interior has responsibility for most of our nationally owned public lands and natural resources. This includes fostering the wisest use of our land and water resources, protecting our fish and wildlife, preserving the environmental and cultural values of our national parks and historical places, and providing for the enjoyment of life through outdoor recreation. The Department assesses our energy and mineral resources and works to assure that their development is in the best interests of all our people. The Department also has a major responsibility for American Indian reservation communities and for people who live in Island Territories under U.S. administration.

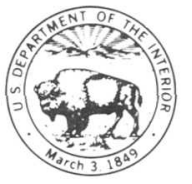

\section{River Basins of the United States:}

\section{The Colorado}

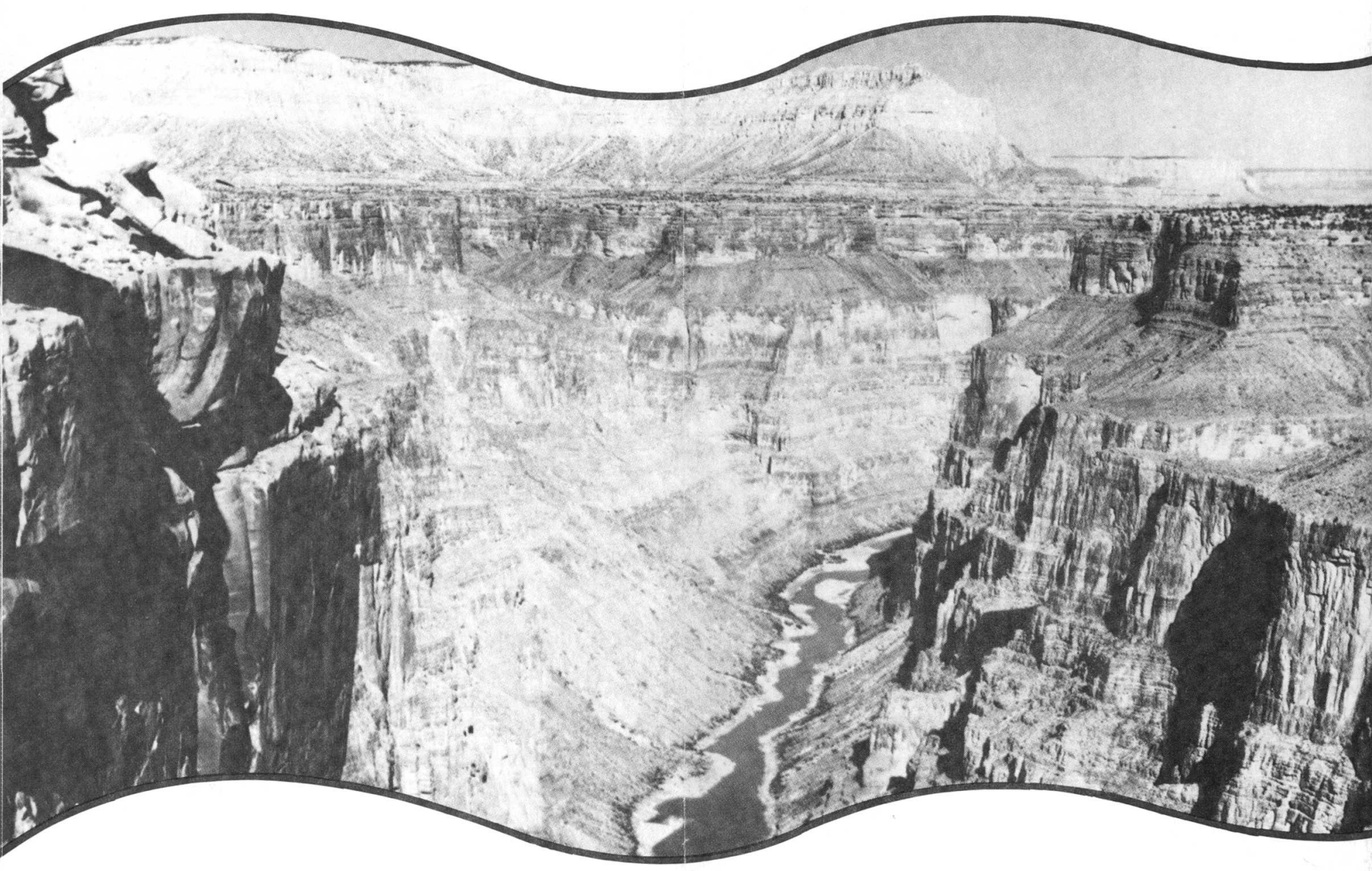

U.S. Department of the Interior/Geological Survey 
River Basins of the

United States:

\section{The Colorado}

This leaflet, one of a series on the river basins of the United States, contains information on the Colorado River Basin, including a brief early history, a description of the physical characteristics, and other statistical data. At present, other river basins included in the series are The Columbia, The Delaware, The Hudson, The Potomac, and The Wabash.

\section{Early Exploration and Settlement}

Francisco de Ulloa, a Spanish soldier and explorer, was probably the first European to see the Colorado River. In 1776, Father Garces, a Spanish missionary, named it the "Rio Colorado." Congress applied the name "Colorado" to the entire river in 1921. A prehistoric race called the Hohokam lived and vanished in the Salt River Valley before the Hopi and the Pueblo Indians inhabited the area. Father Eusebio Kino established the Jesuit missions in 1700 at San Xavier Del Bac and in 1732 at Guevavi, both in Arizona. The first European settlement was established near present-day Tucson, in 1776.

\section{Headwaters}

The river rises in the Rocky Mountain National Park in northcentral Colorado; it becomes a perennial stream near Poudre Pass in Colorado.

\section{Mouth}

The Colorado flows into the Gulf of California. The approximate latitude at the mouth is $32^{\circ} \mathrm{N}$. and the approximate longitude is $115^{\circ} \mathrm{W}$.

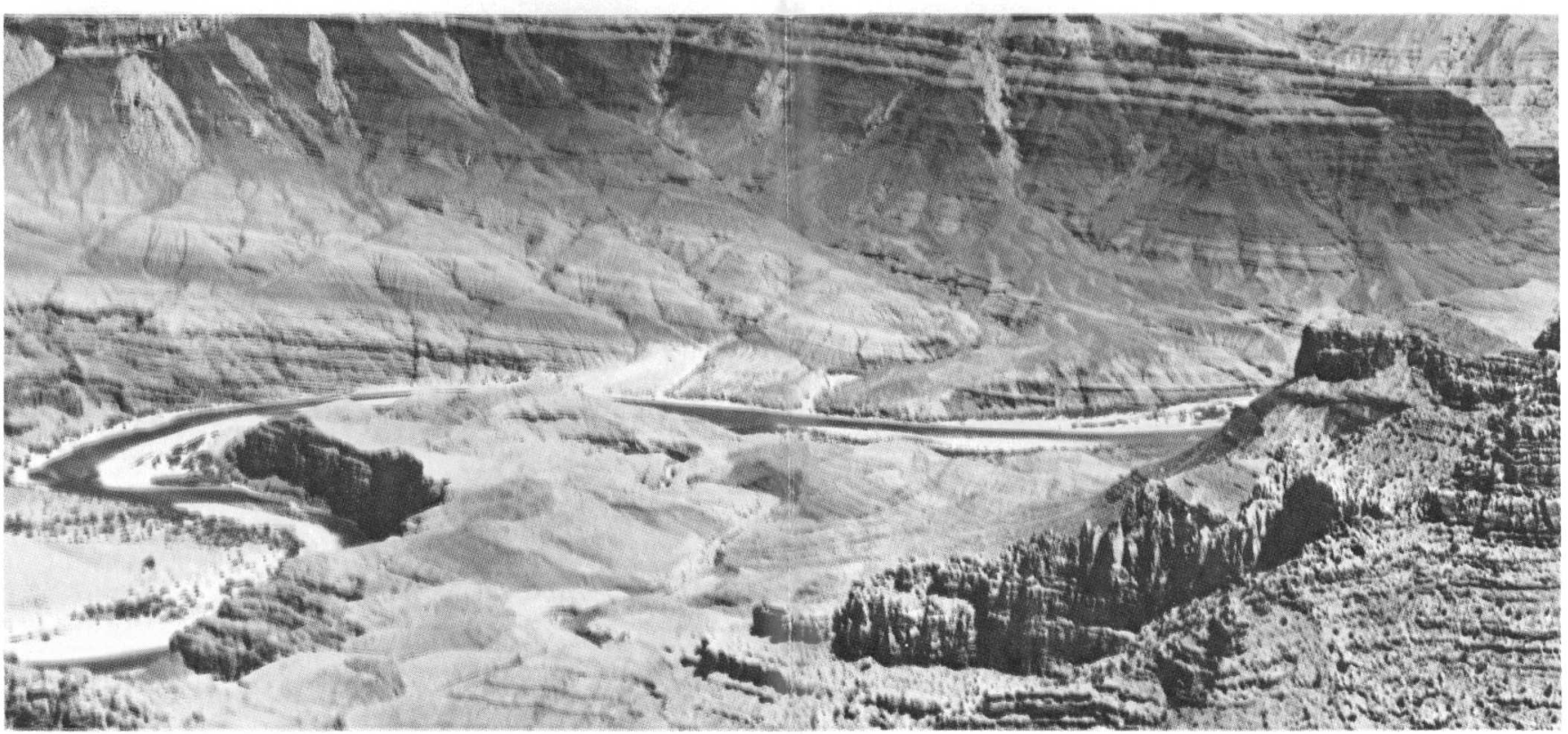

\section{Major Tributaries}

The Gunnison, White, Yampa, San Juan, Delores, Green, Little Colorado, Gila, and Virgin Rivers are major tributaries of the Colorado.

\section{Course}

From its headwaters, the river flows southwestward in a series of meanders across the high Colorado Plateau into southeastern Utah and through northwestern Arizona. Slashing through a wilderness of mountains, plateaus, and deserts, it is cliffbound nine-tenths of its way and travels 1,000 miles through deep canyons. The Grand Canyon is the largest, the deepest, and the most spectacular. The Colorado then bends south to form boundaries between Nevada and Arizona and between Arizona and California. It flows into the Gulf of California, after first forming the boundary between the Mexican States of Sonora and Baja California.

\section{Length}

The Colorado River is approximately 1,440 miles long from its headwaters to its mouth in the Gulf of California. It ranks 6th among 135 U.S. rivers that are more than 100 miles long.

\section{Width}

The river is about 50 feet wide for the first 50 miles; at Grand Junction, Colo., it is 200 feet wide.

\section{Depth}

The river is about 30 feet deep in lower reaches of the Grand Canyon; it is not more than 10 feet in the upper reaches above the Grand Junction, Colo.

\section{Rate of Flow}

Near Lees Ferry, Ariz., the river's rate of flow is about 8 million gallons per minute (gpm); at the mouth it is about 2 million gpm. 


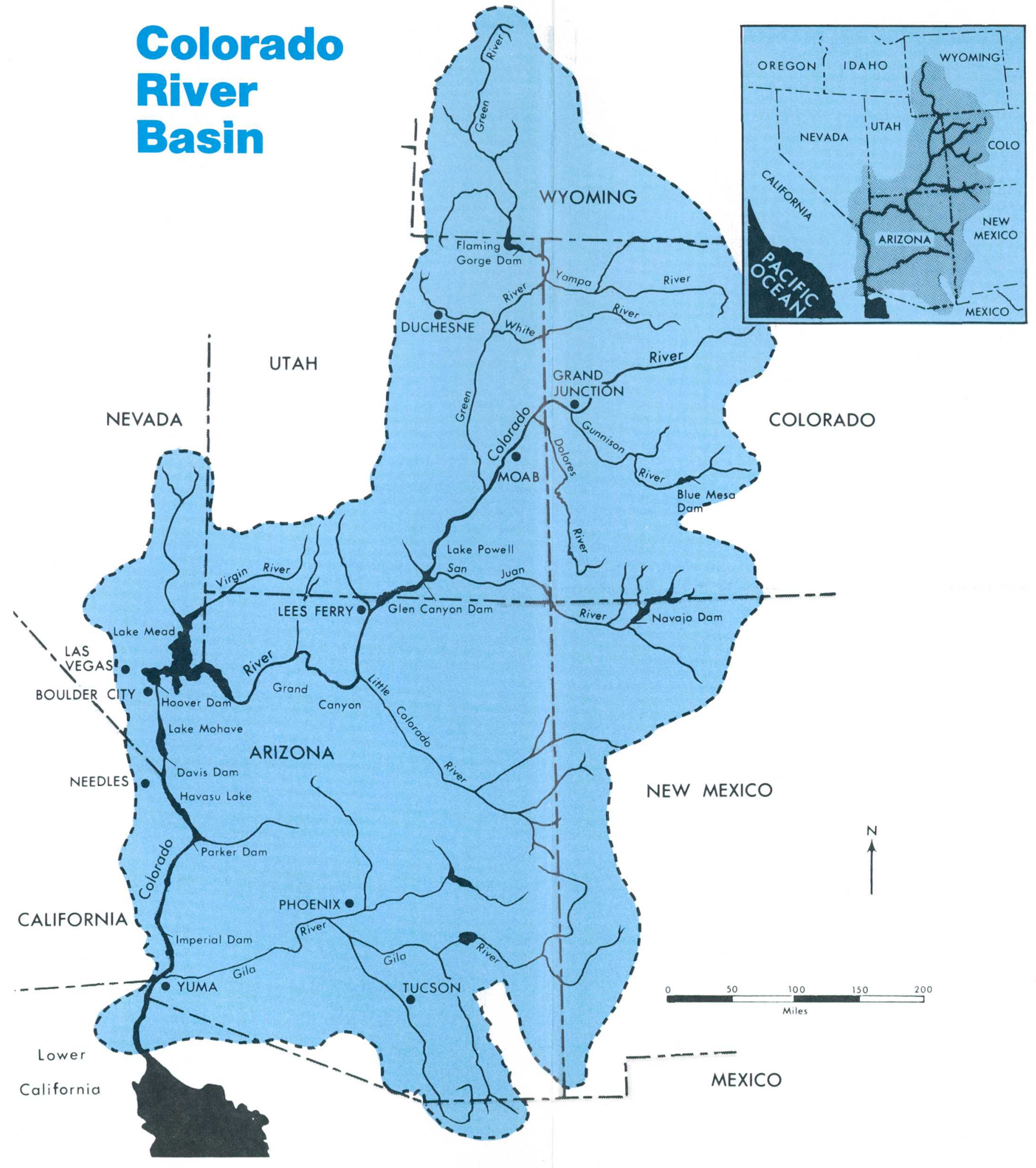




\section{Mighest and Lowest Flow}

The highest recorded flow occurred at Yuma, Ariz., in 1916; the lowest natural (unregulated) flow occurred at Lees Ferry in 1924.

\section{Dams, Reservoirs, and Canals}

The Flaming Gorge Dam, Utah; the Navajo Dam, N. Mex.; the Glen Canyon Dam and Lake Powell, Ariz., and Utah; the Blue Mesa Dam, Colo.; the Hoover Dam and Lake Mead and Davis Dam and Lake Mohave, Nev.; and the Parker Dam and Havasu Lake and Imperial Dam, Ariz., are all a part of the Colorado River.

\section{Geologic Setting}

The Colorado River Basin lies in three physiographic provinces: Southern and Rocky Mountain, Basin and Range, and Colorado Plateau. About 240,000 square miles are arid to semiarid. The Colorado Plateau is composed of horizontal, sedimentary rock strata (sandstone, limestone, shale, conglomerate) which were uplifted thousands of feet, faulted, and carved by erosion into broad plateaus, mesas, buttes, natural bridges, and deep canyons.

The Colorado Desert in the southwestern part of the basin is extremely arid and hot. Most of it is below sea level.

\section{Drainage Area}

The basin area is 243,000 square miles and includes parts of Wyoming, Colorado, Utah, New Mexico, Nevada, Arizona, and California.

\section{Average Rainfall}

An average of about 15 inches of rain falls annually over most of the basin, with a range of 5 inches in the Arizona deserts to more than 50 inches in the Colorado mountains.

\section{Qualiiy}

The river once was one of the most siltladen streams in the United States; now reservoirs trap most of the sediment. The average salinity is less than 50 parts per million (ppm) in headwater areas but often exceeds $1,000 \mathrm{ppm}$ at the international boundary. Pollution from municipal and industrial wastes is slight except in the vicinity of cities and towns. Most ground water used for irrigation is not treated; that used for municipal supply is chlorinated.

\section{Major Cities}

Phoenix, Ariz., is the largest city in the basin. Cities of lesser size are Duchesne and Moab, Utah; Grand Junction, Colo.; Boulder City and Las Vegas, Nev.; Tucson and Yuma, Ariz.; and Needles, Calif.

\section{Municipal and Industrial Water Use}

Water use is limited because the basin is sparsely populated; it is one of the least populated areas of its size in the Western Hemisphere. The principal uses are hydroelectric power generation and irrigation which consumes nearly the entire flow. Large quantities of water are also diverted to adjacent areas for municipal, industrial, and irrigation uses. About 2 million people in the basin use approximately 400 million gallons of publicly supplied water each day and about $1 / 4$ of a million people in rural areas use approximately 25 million gallons of ground water daily.

\section{Commercial Water Use}

The river and its system of dams provide facilities for flood control, irrigation, hydroelectric power; and boating, fishing, skiing, and swimming.

\section{Agriculture}

Agricultural products which come from the basin are: fruits, some cotton, general farming, and grazing. Irrigated agriculture is practiced in every State in the basin.

\section{Industry}

Little industrial development exists in the basin except light industry in the Phoenix, Ariz., area.

\section{Minerals}

Minerals found in the basin are: uranium, zinc, silver, molybdenum, copper, gold, lead, coal, petroleum, and oil shale.

\section{Water Data}

The Hydrologic Data Network, maintained by the U.S. Geological Survey in cooperation with the individual States, is the chief source of basic data on water in this country. In cooperation with other agencies, the U.S. Geological Survey maintains 16,500 gaging stations that measure high and low flow of rivers, lakes, and streams; 27,500 observation wells that collect data on levels and pumpage of ground water; and 8,200 stations that measure water quality.
This publication is one of a series of general interest publications prepared by the U.S. Geological Survey to provide information about the earth sciences, natural resources, and the environment. To obtain a catalog of additional titles in the series "General Interest Publications of the U.S. Geological Survey," write:

Book and Open-File Reports Section

U.S. Geological Survey

Federal Center, Box 25425

Denver, CO 80225 